\title{
Soft Power to Whom? A Critical Analysis of the Publicity Film "CPC (Communist Party of China) is With You Along the Way" in Relation to China's Soft Power Project
}

\author{
Xin Xin, University of Westminster, UK, x.xin1@westminster.ac.uk
}

\begin{abstract}
The existing literature on China's soft power is mainly concerned with its success or failure, ignoring the ideological tensions between the Chinese state's international pursuit of soft power and its efforts at reviving the popularity of socialist ideology at home in a country profoundly transformed by modernisation and globalisation processes. This article argues that such ideological tensions should be contextualised and critically analysed by employing an approach informed by critical globalisation studies, particularly by the power-to-whom critique. It offers a critical analysis of the CPC is With You Along the Way film, a notable recent example of the CPC's publicity videos in the context of its pursuit of soft power. Borrowing Reisigl and Wodak's discourse-historical approach (DHA) in addition to the analytical devices for the study of ideology from Eagleton and van Dijk, the article argues that CPC is With You Along the Way illustrates a shift in the party's ideological approach to the question '(soft) power to whom?'.
\end{abstract}

Keywords: ideology, China, soft power, globalisation, Chinese dream, discourse-historical approach

Acknowledgement: I wish to thank the three anonymous reviewers and Professor Christian Fuchs for their helpful feedback on earlier versions of this article.

\section{Introduction}

This is an ancient and youthful country

It is growing fast yet with development disparities

It's full of opportunities

along with untold challenges

but its 1.3 billion people

all have their own dreams

[Voices from different people:]

"I want a good harvest next year"

"I want to start a diner"

"I want some more pensions"

"I want a pretty wife"

"I want azure sky and cleaner water"

"I want a world free of wars"

Our people's dreams

are our goals

the 80 million CPC members

together with the entire population

are working for everyone's dream

for every dreamer to have a stage

and for every dream seeker on the stage

to have an opportunity for success

to have the joy of a dream-come-true 


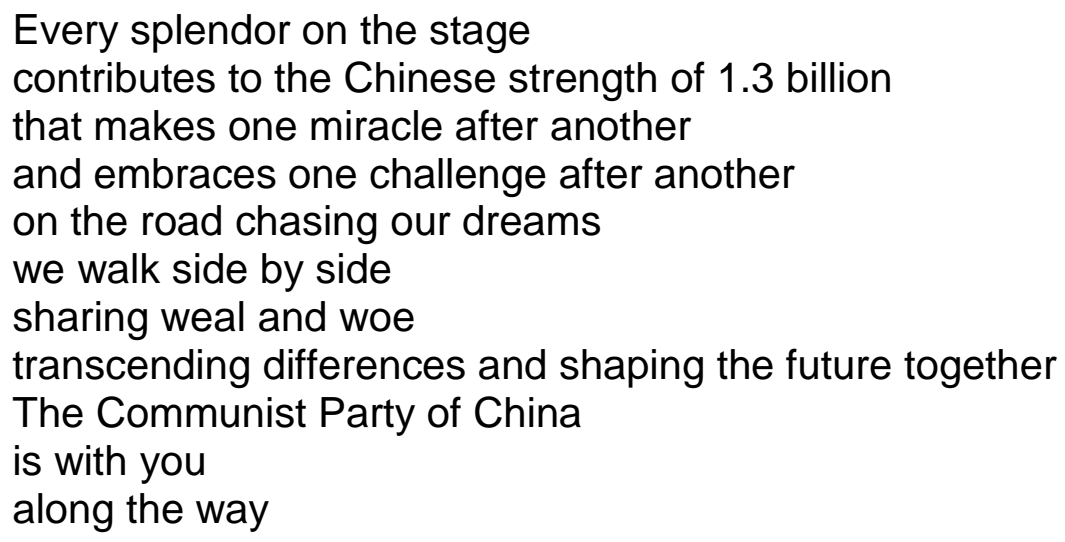

This is the script of a short film titled CPC is With You Along the Way (2014). The film has been officially endorsed by People's Daily, a leading organ of China's ruling party since 1949, which indicates its importance to and its recognition by the party (Zhang 2015). The short film was produced by the mysterious Fuxing Road Studio soon after $X i$ Jinping had become the President of the People's Republic of China (PRC) in March 2013 (Zhang 2015). The same studio, the ownership of which remains obscure, has in recent years released a number of English-language publicity videos, strictly following the Communist Party's line under Xi's leadership. ${ }^{2}$ Because of its relevance to China's controversial soft power project, the CPC is With You Along the Way film is worth examining critically, which is what this study aims to do.

James Areddy (2014), the Wall Street Journal's China reporter, refers to this film as a notable effort by Chinese authorities under Xi's leadership "to invoke soft power through video". Yuezhi Zhao (2015), a leading scholar of the political economy of communication in China, suggests that this film has done more than just promote China's soft power. Through the film, Zhao argues, the CPC has sent out a clear message that the party is willing to stand alongside ordinary Chinese people and help their dreams come true, in keeping with the party's mantra about the 'Chinese dream' (2015). The latter can also be seen as an updated version of China's soft power project (Servaes 2016). Such a top-down message is ideological in the sense that it also intends to show an alternative to the ongoing capitalist crisis (Zhao 2015). This is in sharp contrast to an earlier publicity video from $2011^{3}$, which was more prominent, having famously been shown on the giant screen in Times Square in New York City, showcasing the various achievements of celebrities and members of the Chinese elite. More importantly, the CPC is With You Along the Way film appears to display a different approach to the question: (soft) power to whom? This issue was only vaguely handled in the 2011 video, which had external audiences primarily in mind, whereas the CPC is with You Along the Way video is more focused on Chinese audiences' wants and hopes when it comes to projecting China's soft power. This question essentially concerns the legitimacy of the CPC, the source of which originally lay in the legacy of socialist ideology. In the process of modernisation and globalisation, socialist ideas have gradually lost ground to an increasingly dominant neoliberal ideology. Joseph Nye's highly influential concept of soft power within China (1990a; see also Nye 1990b; 2004) is also consistent with neoliberal ideology.

${ }^{1}$ https://www.youtube.com/watch?v=Og--XLr 5L8 (accessed 4 December 2019).

2 https://qz.com/533850/chinas-craziest-english-language-propaganda-videos-are-made-byone-mysterious-studio/ (accessed 4 December 2019).

3 http://www.chinadaily.com.cn/cndy/2011-01/19/content 11877488.htm (accessed 4 December 2019). 
Despite its neo-liberal origin, soft power (软实力) became a popular discourse in mainland China, especially after 2007 (Barr 2011; Li 2008; McGiffert 2009; Suzuki 2010; Wang and Lu 2008; Zhao 2013). The former President Hu Jintao stressed the importance of soft power in his 2007 annual keynote speech to all members of the CPC, urging the country to enhance its still-weak soft power (McGiffert 2009). Since then, China's soft power project has been in full swing, as witnessed by the launch of a number of eye-catching cultural, media and communications initiatives involving lavish infrastructure and business expansion overseas (2009). The existing literature on China's soft power project is mainly concerned with the country's media and cultural expansion and provides an assessment of its successes and failures (Zhao 2013). It tends to ignore the underlying ideological tensions inherent in such a project, namely the contradictions between Chinese state authorities' pursuit of soft power internationally and their efforts to revive the popularity of socialist ideology at home in a country profoundly transformed by modernisation and globalisation processes.

This study thus argues that such ideological struggles, no matter how sophisticatedly mediated and communicated in the age of digital media, are inherent and unavoidable, and will tend to intensify in the ongoing process of globalisation and modernisation. Hence they deserve greater attention in academic discussions on China's soft power.

The current study employs a theoretical approach informed by critical globalisation studies, particularly by the power-to-whom critique. The 'power to whom' question is concerned with the identity of the targets of soft power efforts: whether, for instance, those efforts are primarily aimed at internal or external audiences, elites, or ordinary people. The question 'power to whom' (and related, but different, questions such as 'power exercised by whom' and 'power to what ends') has been asked by critical globalisation scholars seeking to problematise the "globalisation project" (GP)(Robinson $2005,13)$. For critical globalisation scholars, the GP is closely linked with neoliberalism, an economic and political ideology which rose to dominance in the major Western powers, notably in the US and the UK, in the late 1980s and early 1990s (Chase-Dunn and Gills 2005). Glorifying "the efficiency of markets and privately held firms" by attacking "labor unions, entitlements, and other institutions that have protected the incomes of workers", the GP has triggered waves of resistance and controversy since the beginning $(2005,45)$. It has been in a constant state of crisis due to overconsumption and overproduction, in addition to military overstretch (Harvey 2005).

This was also the case for the US in the 1980s and 1990s. US elites thus considered ideological innovation to be a pressing task in order to "sustain U.S. hegemony and global capital accumulation through a mixture of multilateral consent backed by coercion" (Harvey 2005, 98-99). It is against this backdrop that Nye coined the notion of soft power (1990a; see also Nye 1990b; 2004). Therefore, Nye's conception of soft power needs to be critically examined in relation to the GP and the 'power to whom' question, which is also what this study aims to do.

After having provided an overview and anticipated the overarching argument in this introductory section, the rest of the article is divided into six sections. Section 2 discusses the major methodological issues with a focus on the main methods used for collecting primary evidence. Sections 3 and 4 set up the analytical framework within which this study is situated. Section 5 provides the historical context of the study, which also forms part of the contextual analysis of China's soft power project. Section 6 presents a critical discourse-historical analysis of the short film. The final section draws some conclusions and makes some recommendations for further study. 


\section{Methodology}

Texts frequently serve as "sites of social struggle, in that they manifest traces of a range of ideological struggles for dominance and hegemony" (Reisigl and Wodak $2016,26)$. For critiquing or resisting such ideological hegemony embedded in the texts, it is essential to take a critical approach to analyse them, such as placing the textual or linguistic analysis in a historical and social context, identifying the social positions of the discourse or textual participants, and "engaging in continuous self-reflection while undertaking research" $(2016,26)$.

In order to critically examine and assess the ideological implications of China's soft power project in general and that of the publicity film CPC is With You Along the Way in particular, this study offers a critical discourse analysis of the film. In particular, it borrows from Reisigl and Wodak's (2016, 24-25) discourse-historical approach (DHA), analysing the chosen film in three related aspects:

- Firstly, it contextualises China's soft power project in general and the film specifically with a special focus on the issues that are latently expressed in the film but ideologically "manipulative" $(2016,25)$. Methodologically speaking, this implies a provision of contextual and historical knowledge about mainland China in relation to its soft power project and draws on relevant social and critical theories in order to develop a "social diagnostic critique", suggested by Reisigl and Wodak $(2016,25)$;

- Secondly, it identifies textual or linguistic inconsistencies and self-contradictions in the film in order to develop an "immanent critique" of the inherent ideological tensions discussed earlier $(2016,25)$;

- Thirdly, it reviews the two above types of critique and makes some recommendations accordingly in the concluding section of the article; this is part of seeking an alternative approach in order to be able to develop a "future-related prospective critique" $(2016,25)$.

Given the main aim of this article, the first aspect will be the major focus of the DHA analysis (and also provide an understanding of the context that is necessary for discussing the latter two aspects in the article). To triangulate the DHA analysis with a focus on the first two aspects, this article also employs some analytical approaches to the study of ideology from Eagleton (2007) and van Dijk (1998), such as Eagleton's definitions of ideology and van Dijk's ideological devices. These analytical tools will be explained in detail in Section 4.

\section{Problematising Nye's Conception of Soft Power}

According to Nye (2004), soft power is the power of attraction. The power-for-whom question seems irrelevant to Nye's notion of soft power, created primarily for countering the "American decline" thesis (1990; see also Nye 2004; 2008; 2011; 2013; 2015). In spite of growing doubts over the credibility of the US and its ability to lead the world, Nye has consistently argued that such American leadership will continue for several decades at least. In his book Is the American Century Over?, Nye (2015) concludes that the USA's capability to maintain its global leadership in world affairs is an epistemological issue: if everyone believes that the American century will continue for decades, this belief alone will help the US gain enough strength to remain in its leadership position (2015; Rachman 2015). Thus, Nye seems also to imply that the American decline, rather than being the consequence of the country's "overstretch", stems from the growing popularity of the "American decline" thesis since the late 1970s (Ferguson 2003; Kennedy 2010) 
In order to counter the "American decline" thesis, Nye has been at pains to argue that American values are "universal values". According to Nye, "the United States benefits from a universalistic culture" $(2004,11)$ and the American "universalistic culture" serves not only as America's unique soft power resource, but also as the only real alternative to other cultures (Zahran and Ramos 2010,12-31). But Nye tends to ignore the fact that "ideas are always relative, they originate in a given society or culture, they are not absolute and usually mean different things for different people" (Zahran and Ramos 2010, 24). In order to spread ideas and values, there are always ideological or hegemonic struggles involved, which Nye largely overlooks in his treatment of soft power.

Moreover, Nye's soft power project, similar to the "globalisation project", "glorifies the efficiency of markets and privately held firms" (Chase-Dunn and Gills 2005, 45). According to Nye, the private sector is important in terms of generating America's soft power around the world (2013; see also Nye 2015). An example Nye often uses in his analysis of the success of America's soft power is the Hollywood film industry. This is in spite of the many controversies surrounding Hollywood, for example, over the violent or discriminatory content of many of its movies (Taylor 2010; Thussu 2013). Nye also seems very fond of private ownership of TV news production in general. He argues that private ownership is one of the major reasons why CNN is able to stand out from the crowd and is more popular than other broadcasters, particularly state-funded broadcasters in China, Russia, and Iran. For Nye, a better alternative to America's model does not exist. Nye seems to have taken measurements such as profit, popularity, and the level of state policy intervention for granted, and thus uncritically employs them in his assessment of a cultural industry's success/failure or a country's cultural attraction/limitations. In this regard, Nye's approach is rather problematic and Americacentric (Thussu 2013).

Nye's concept of soft power, similar to Francis Fukuyama's theory of "the end of history" (1992), is largely based on the assumption that the American model's "Washington Consensus" represents the ultimate form of political organisation (MacKenzie 1994). Other forms of political organisation are seen as either irrelevant or lacking in credibility. However, such a view is likely to lead to "the end not of history but of critical thought" (Robinson 2005, 15). In this sense, a critical examination of Nye's soft power project is not only useful but also necessary in order to preserve critical thought.

In analysing the importance of America's leadership and its long-lasting effects, Nye makes numerous comparisons between the USA and other great powers, such as China and Russia. In Nye's eyes, neither China nor Russia will ever be able to achieve the type of charisma that the US possesses in terms of soft power in the eyes of the public in Western liberal democracies (2013). According to Nye, China's soft power deficit is largely determined by the country's choice of political system. He suggests that America's set of political values and institutions in its entirety is a better alternative to China's, no matter how imperfect the American political system is (2004; see also Nye 2011; 2013; 2015). In this respect, Nye, like Fukuyama, shows a cavalier confidence in "the stability and ever-widening appeal of liberal democracy" (McLellan 1995, 78). Akin to Fukuyama, Nye also arguably underplays the challenges posed by the rise of alternative ideologies, notably feminism, ecologism, and fundamentalism, as well as the political and social upheavals triggered by financial crises (such as the 1997 Southeast Asian crisis and the 2008 financial crisis). This shows that ideological (rather than civilisational) clashes have never ended. Quite the opposite, they have been intensifying, even within the West (Appelbaum and Robinson 2005). As such, 
though he rarely mentions the word 'ideology' in his writing, Nye has used his concept of soft power as the new ideology of the 'American century'.

\section{Soft Power as Ideology}

Although Nye's conception of soft power is very much informed by neoliberal ideology, he carefully avoids using the actual word 'ideology' in his discussion of America's soft power. One of the few exceptions can be found in Nye's (2004) book on soft power:

If a country's culture and ideology are attractive, others more willingly follow. If a country can shape international rules that are consistent with its interests and values, its actions will more likely appear legitimate in the eyes of others. (Nye 2004,10)

In this passage, ideology is somehow equivalent to a set of political values and is seen to be just as important as culture in terms of generating a country's soft power. However, Nye uses the word 'ideology' cautiously in his writings in order to distance himself from the negative connotations of the word in the West. Nye usually replaces the term 'ideology' with either 'political values' or 'foreign policies'. Culture, political values, and foreign policy constitute the three main soft power resources of the USA (Nye 2004, 11).

The negative connotations of the term ideology partly derive from the early Marxist tradition, notably Engels's famous view of ideology as a false consciousness. These negative connotations were reinforced during the Cold War when "ideology" was used in bourgeois critiques of socialism (McLellan 1995). In general, ideology has always been a vaguely defined, albeit widely used, concept in the social sciences, in political discourse, and in the mass media (van Dijk 1998). The notion of ideology was first coined by French philosopher Destutt de Tracy in the late 18th century (McLellan 1995). However, its origins are usually considered to lie in "the social, political and intellectual upheavals that accompanied the Industrial Revolution" $(1995,2)$. In the context of the Industrial Revolution, ideologies firstly emerged in the process of forming new worldviews, which originated from "the spread of democratic ideals, the politics of mass movements, the idea that, since we have made the world, we can also remake it" $(1995,2)$. While claiming "a scientific character", the critique of traditional interpretations of the world had to establish new legitimations of power "by appearing in the mantle of modern science and by deriving their justification from the critique of ideology" (Habermas 1970, 99, quoted in McLellan 1995, 2). As such, "ideologies in the restricted sense first came into being" $(1995,2)$. Jürgen Habermas suggests that "ideologies are coeval with the critique of ideology. In this sense there can be no prebourgeois ideologies" $(1995,2)$.

In certain contexts, one person's epistemology can be another's ideology (MacKenzie 1994). Moreover, there is a methodological dilemma, as David MacLellan points out:

Any examination of ideology makes it difficult to avoid the rueful conclusion that all views about ideology are themselves ideological. But avoided it must be - or at least modified by saying that some views are more ideological than others [...] A more discriminating approach is therefore necessary not only intellectually but also practically: we are indeed all implicated in ideology which is both real and powerful; but an understanding of this fact can at least prevent us from becoming its unconscious victims. (1995, 1-2) 
Bearing these ideological paradoxes in mind, this article makes no attempt to argue that only Nye's conception of soft power is ideological. Rather, it puts forward a somewhat different approach to conceptualising soft power. Hence the 'soft power as ideology' thesis is countered to the 'end of ideology' argument. This article argues that soft power is not an organic type of attraction free from any ideological influence, as implied by Nye. Rather, the notion of soft power, despite being presented in a new bottle as a novel political idea, actually derives from neoliberal ideology and has become an ideology in its own right.

Terry Eagleton $(2007,28-30)$ proposes six definitions of ideology, which follow a logical order, ranging from the most neutral/general definition of ideology to the most negative one. He accordingly defines ideology as 1) "the general material process of production of ideas, beliefs and values in social life"; 2) ideas and beliefs of "a specific, socially significant group/class"; 3 ) ideas and beliefs employed for promoting and legitimating the interests of the groups that face opposing interests; 4) ideas and beliefs used for promoting and legitimating particularistic interests of a dominant group; 5) ideas and beliefs employed for legitimating the interests of a dominant group/class by reality distortion; and 6) false or deceptive beliefs that emerge within the material structure of society as a whole. The working definition of ideology adopted in this study falls somewhere between the fifth and the sixth definitions above. The rationale for choosing the most negative interpretations of the concept of ideology is that this study aims to develop a critique of Nye's conception of soft power and how it has been applied to China.

For Eagleton $(2007,56)$, "[a]n important device by which an ideology achieves legitimacy is by 'universalizing' and 'eternalizing' itself". This means that "[v]alues and interests which are in fact specific to a certain place and time are projected as the values and interests of all humanity" $(2007,56)$.

For van Dijk (1998), ideology can also be seen as a discourse, which is more than a form of language. He calls for a critical examination of ideology by looking into how in-groups and out-groups are divided within a society. The devices employed for detecting such an ideology include but are not limited to: 1) membership devices (Who are we; who belongs to us?); 2) typical activities/actions (What do we do?); 3) aims (Why do we do this?); 4) values/norms (What are our main values? What should (not) be done?); 5) position (What is our position in society? Who are our enemies/opponents?); 6) resources (What are the essential social resources that our group has or needs to have?). Here the main resources include access to public discourse (van Dijk 1998, 69-70).

Each device/category listed above functions "as the organising pattern of a number of basic evaluative beliefs", which are by definition ideological (van Dijk 1998, 70). Each device "may be needed to define all groups, but groups may also be identified specifically by one particular category" $(1998,70)$. For example, feminism can be seen as a typical goal-oriented ideology, "defined by the hierarchically most important belief of the ideology, namely, to arrive at full equality for women and men" $(1998,70)$.

In relation to Nye's conception of soft power, the membership device plays an important role in enabling the ideological distinction between in-groups, such as the USA, and out-groups, such as China, when discussing the success or failure of soft power. Nye's emphasis on the importance of "universal/American values" is also an ideological manifestation of the function of the main device. This can also be explained by Eagleton's theory on how to legitimise an ideology (such as soft power) by universalising and externalising American/Western values and interests, which are in fact specific to the American or Western context but "projected as the values and interests of 
all humanity" $(2007,56)$. Essentially, Nye's notion of soft power serves as a goal-oriented ideology for legitimating and universalising America's hegemonic dominance in the world, despite its gradual decline. The understatement of the power-to-whom issue in Nye's conception of soft power serves a similar purpose to the purpose served in "the globalisation project" by understating the transnational capitalist class as the main beneficiary of globalisation, leading to subsequent 'class unconsciousness'.

For the purpose of this study, Eagleton and van Dijk's approaches to ideology will be adopted in order to examine China's soft power project through the publicity film CPC is With You Along the Way. By contextualising the film, this article will discuss how the main ideological devices are deployed for promoting the party's socialist ideology in relation to the '(soft) power to whom' question, with the aim to legitimate China's soft power project. The following section will review China's soft power project from a historical perspective, setting the scene for the contextual and textual analysis that follows.

\section{Why is China so Concerned with Soft Power?}

Nye's notion of soft power was introduced to mainland China as early as the beginning of the 1990s (McGiffert 2009; Wang 1993). However, the practice of pursuing soft power is not new to China. The idea of getting others to want what one wants through the power of example, ideas, and persuasion can, in China, be traced back to Lao$\mathrm{Tzu}$, the Chinese philosopher who lived in the 6th century BC. ${ }^{4}$ The fact that Nye's concept of soft power instead of Lao-Tzu's “Dao” (道) or “Kingly Dao” (五首) has entered the PRC's official discourse on the state's 'comprehensive national power' (综合国力) in the early 21st century is itself an illustration of America's soft power - the power of ideas.

To exercise the power of ideas is also not a new practice in contemporary China. This is especially true of the power wielded through adopting modern means of communications for the promotion of the CPC's revolutionary history among Chinese and foreign publics. Chairman Mao Zedong was famous for engaging effectively in such practices. His political ideas, summarised as 'Mao Zedong Thought' at home or 'Maoism' outside China, were, by Nye's definition, a source of Chinese soft power, though its political and social impact on Chinese and foreign societies remains controversial. 'Mao Zedong Thought' was essentially the localisation of Marxism and Leninism to the Chinese political and social context (D'Mello 2009; Zhao 2013). It combined Mao's interpretation of the two schools of critical thought with his understanding of Chinese social reality in the first half of the 20th century. It also aligned with his and other key party members' political ambitions and ideals. The application of Mao's political ideas to Chinese society during a long period of revolutionary struggles against imperialism, colonialism and feudalism was also linked with the authoritarian style of one-party-rule (Zhao 2013).

Mao's political ideas were promoted largely through the CPC's 'propaganda system', which consisted of both internal and external channels. In this way, Mao's political thought was made appealing to, and followed by, people in many parts of the world, especially between the 1950s and the 1970s. Even today a radical school of Maoism remains influential in certain parts of the developing world, such as India and Nepal, where poverty and social inequality are still major issues. In order to spread his revolutionary ideas to the countries fighting for national independence in the 'Third World'

\footnotetext{
${ }^{4}$ Nye's interview with Guernica magazine in 2008. https://www.guernicamag.com/how soft is smart 1/ (accessed 4 December 2019)
} 
and, to a lesser degree, to those numerous revolutionary groups in the 'Second World' and the 'First World', Mao urged the state news agency, Xinhua, to increase its international presence by setting up overseas bureaus in the late 1950s (Xin 2012).

The power exerted by Mao over Xinhua and other state-owned media stimulated the early development of the PRC's international broadcasting and information system - a key aspect of the state's early public diplomacy practice, traditionally referred to as “foreign propaganda" (外宣). Xinhua's recent overseas expansion under the 'Going Out' project (走詓工程 was similar in nature and intent to the earlier initiatives undertaken by the news agency (Xin 2012; Zhao 2013). The 'Going Out' project started in the late 1990s under the initiative of then-President Jiang Zemin. It was originally a strategy designed to minimise the negative impact of the 1997 Asian financial crisis on the Chinese economy. State-owned industrial and trade enterprises were encouraged, and provided with financial support, to expand their businesses in Africa, Latin America, and other emerging markets not affected by the crisis. Later, in the early 2000s, the initiative was extended to the cultural and communications sectors and was aimed at projecting a positive image of China overseas through the party-controlled 'foreign propaganda' system.

Contemporary Chinese history also shows that the impact of Mao's thought or 'soft power' was not always positive and peaceful. Numerous political and ideological campaigns were launched at home under Mao's leadership, culminating in the disastrous 'Cultural Revolution' (1966-1976). For a decade, Mao's political power, essentially the power of his ideas, was abused by the 'Gang of Four' led by Mao's wife, Jiang Qing. During this period, Mao's political ideas were turned into dull doctrines, distorted and radicalised (MacFarquhar and Schoenhals 2008). The Cultural Revolution also serves as a vivid illustration of how soft power can be abused under certain circumstances. Since the end of the Cultural Revolution, Mao's ideational influence on post-Mao generations within Chinese society gradually faded away, particularly in economically-developed coastal areas (Zhao 2012). Consequently, this created an 'ideational void' that needed to be filled with new ideas. In this context, the popularity of Nye's concept of soft power within Chinese society is not merely a coincidence.

On the other hand, the decline of Mao's influence on Chinese society has not been linear. There have also been signs of revival in recent years as the gap between the rich and the poor has widened. This has raised serious questions about the legitimacy of the monolithic rule of the CPC and the socialist system that the party has tried to build since 1949 (Zhao 2012; see also Zhao 2013). In order to legitimate the rule of the CPC, Chinese political elites often turn to Mao's theories for political references and arguments.

It is also interesting to note that both the fallen politician Bo Xilai and President Xi Jinping have found Mao's thinking inspiring, and they have both promoted Mao's views on the issue of economic and social inequality for their own political ends (Zhao 2012). This shows that the Maoist legacy is still present in today's China. But it is in constant ideological conflict with the logic of the free market economy pushing China's economic integration into the global capitalist system. In these circumstances, Nye's neoliberal thinking on America's soft power has provided the emerging Chinese transnational capitalist class with an ideology covered by a soft shell.

Having gone through profound economic, political, social, and cultural transformations in the past four decades, today's China still retains a number of striking "Chinese characteristics", which are mostly received negatively outside China (Callahan 2012; Kissinger 2012). The expression "Chinese characteristics" in Chinese political discourse was originally used to refer to the CPC's political experiment based on the application 
of socialist/Marxist-Leninist theories to the complex Chinese social reality of the 1940s and 1950s (Callahan 2012; Kissinger 2012). Over the past three decades, the usage of the expression has gradually expanded. It was used in relation to the handling of the transfer of sovereignty of Hong Kong and Macao in 1997 and 1999 respectively, when the famous 'One Country, Two Systems' theory was formulated. It is also used with reference to the mixed political economy of today's China - its authoritarian polity and market economy. In the realm of media and communication, the term "Chinese characteristics" has been often used to refer to the fact that the process of marketisation has unfolded without the state/party lifting control over media ownership and content, particularly in the news and current affairs sector (Chan 1993; Zhao 1998; see also Zhao 2008).

According to Henry Kissinger (2012, xiv), China's emphasis on its "Chinese characteristics" can also be explained by Chinese exceptionalism, more accurately China's "cultural universality". China's status as "the heir of the Middle Kingdom tradition" has been subtly but repeatedly emphasised by Chinese elites (Kissinger 2012, xiv). According to the ancient Chinese tradition, all other states were considered to be "various levels of tributaries based on their approximation to Chinese cultural and political forms" (2012, xiv). This can be seen as a kind of Chinese "cultural universality" (2012, xiv).

Both Chinese and American exceptionalisms tend to work in a similar way: each considers its own society an exceptional and unique case (Kissinger 2012). They can both be seen as the embodiments of the externalised ideologies of their rulers (see Eagleton 2007). In soft power practice, both have in fact followed the same motto: "to know us is to love us" (Taylor 2009, 12). In the American context, this amounts to the idea that "being attractive is sufficient to make others want to be like you" $(2009,12)$. But the tragic 9/11 attacks in 2001 seriously challenged this view within the US. Since then many Americans have begun to ask, 'Why do they hate us so much?' in spite of the large stock of soft power that the country possesses, according to Nye (2004). A process of rethinking US public diplomacy and soft power activities has emerged (Snow 2009).

In the Chinese context, the similar idea that "to love us is to know us" as summerised by Taylor $(2009,12)$ was widely accepted and turned into the tactic of 'going out' and 'speaking louder' via various mostly state-owned media, communications and cultural channels. This was done in order to enhance China's "international communications capacity" (国际抟播力), which is arguably an important source of a country's soft power (Shi 2018). Within the media and cultural realm, Chinese soft power is taken as a natural extension of the existing 'propaganda system' under the CPC's ideological and political control, though it has been modified over the past four decades by adopting certain Western journalistic, communication, public relations and public diplomacy techniques. Beneath these seemingly different soft power approaches, there is a similar sense of cultural ignorance, either US-centric or Sino-centric. In this respect, studying China's soft power project - a case that has not been studied as extensively and systematically as America's - provides a useful comparative perspective for understanding cases other than the US.

According to Nye (2013), what China does not seem to understand about soft power is that it is impossible to achieve its goals under the current authoritarian political structure. The political structure modelled by the US is considered by Nye, if only implicitly, as a necessary resource not only for the US to universalise and externalise its soft power ideology but also for China to legitimate its soft power project outside the 
country. For Chinese leaders, however, soft power is more like an action-oriented ideology, to be built upon the country's rising hard power - a combination of economic, political, and military power by Nye's definition - under the leadership of the CPC. In other words, from China's perspective, the political resources needed to enhance its soft power and realise the 'Chinese dream' are already there. As the argument goes, what China is currently lacking is not a resource-based ideology but an action-oriented ideology, being externalised either as China's soft power or as the 'Chinese dream'. In this sense, the differences between the US and China in terms of interpreting and assessing soft power are ideological in nature.

\section{Critically Contextualising and Textualising the Film CPC is with You Along the Way}

Whose dream ought to be given top priority in today's China? Similar to the (soft) power-to-whom question, this is by nature an ideological enquiry, concerning the legitimacy of the CPC as the PRC's ruling party. The question can also function as a "membership device" in van Dijk's (1998) term, drawing distinctions between in-groups and out-groups within Chinese society as well as between Chinese and non-Chinese societies. However, such an important ideological issue was deliberately sidelined for decades given the de facto de-ideologisation in mainland China during the process of marketisation and globalisation (Zhao 2012; see also Zhao 2013). The de facto de-ideologising process, commencing soon after the Cultural Revolution, for several decades enabled China to concentrate mainly on its economic development and international integration. As a result, socialist ideology has for a long time held the status of a marginalised goal-oriented ideology rather than a necessary resource ideology. Yet the weakening of socialist ideology within Chinese society has not helped China to win the desired respect from Western liberal democracies that still largely see China as a threat (Zhao 2012; see also Zhao 2013). In Nye's view, this is mainly due to the fact that China has not yet adopted America's political system, which he sees as the essential resource needed for advancing China's soft power project. Furthermore, the undervaluation of socialist ideology as a necessary resource to build a socialist society has created an ideological void within the fast-changing Chinese society, paving the way for the subsequent spread of Nye's soft power concept. This has further weakened China's socialist identity and, to a large degree, the CPC's legitimacy as the ruling party, a legitimacy that historically rested on its socialist revolutionary ideas. According to Lenin (1902/1987), to weaken the socialist ideology by even the slightest degree means to enhance its opposing ideology, as discussed earlier. Lenin's view is still familiar to millions of Chinese who survived the Cultural Revolution. During that chaotic decade, Lenin's ideas, including his views on ideology, were distorted and used mostly as political doctrines (D'Mello 2009; MacFarquhar and Schoenhals 2008). Four decades later, the divide between socialist and capitalist ideologies remains, and if anything, has deepened further. However, public support for socialist ideology within mainland China has eroded significantly, especially in comparison with the level of support it enjoyed in Mao's era (Zhao 2012).

In line with Lenin's view, Yuezhi Zhao (2014) thus calls for a re-formulation of critical theories with socialist and internationalist ideologies in order to rebuild the authority of socialist ideology in China. As Zhao suggests, such theoretical reconstruction will serve not only the purposes of soft power, but also help the party-state legitimate itself as a socialist society. In this sense, the film CPC is with You Along the Way could be seen as the starting point for the CPC's recent efforts to revive its socialist ideology. Whether such efforts will be effective or not is another issue. The following discussion 
will first use van Dijk's ideological devices to 'detect' the textual manifestation of such efforts and then try to critically contextualise them in the Chinese context.

At a first glance, the film CPC is With You Along the Way indeed reminds viewers of a familiar type of self-promotion by the CPC. In the film, and even in its title, the CPC makes clear that the party still aims to serve ordinary Chinese people. This 'power-toall-the-people' theme is narrated and framed around the motif of the 'Chinese dream' - a Chinese counterpart to the 'American dream' - coined by Xi Jinping in late 2012 (BBC 2013). In terms of ideological implications, however, both the Chinese dream and the American dream are similar concepts in the sense that they are portrayed as dreams that can be realised by all people within society. The latent reality is that without radical and structural changes, the inherent structural inequalities, in addition to regional socio-economic unevenness within each society, will limit certain groups' opportunities to realise their personal dream(s), let alone the collective version of the Chinese dream or the American dream. In this case, the majority of people, mostly nonelites as portrayed and voiced in the new publicity film, are likely to be placed in the less advantaged position.

In the text of the film CPC is With You Along the Way, only China's "development disparities" have been overtly identified. The structural disparities are either omitted or vaguely alluded to, generalised as part of the bag of "untold challenges" towards the end of the film. By linking the inequality issue with the development issue, the film seems to suggest that the disparity issues confronted by a country of 1.3 billion people can be resolved automatically once China, under the CPC's leadership, further develops economically to a high level, without the need to make radical structural and institutional changes. Such a discourse is, undoubtedly, ideological. On the one hand, it shows the CPC's confidence in its leadership of the country and the political system that the party has created. On the other, it is ideologically 'manipulative' in the sense that it subtly excludes any alternatives and contradictions by sketching a rosy picture of the future, or the Chinese dream, in spite of the country's economic slowdown and other challenges.

In connection to the individual dreams voiced in the film, the Chinese government's top priority remains to develop the country's economy as a response to the first two featured dreamers' wishes: "I want a good harvest" and "I want to start a diner". The film also symbolically touches upon the social, environmental, international, and regional challenges that China is confronting alongside the economic issues through other dreamers' voices. However, no controversial or politically sensitive wishes or dreams are mentioned in the film. Instead, the six dreamers featured in the film all seem happy in a similar fashion, feeling hopeful to be united around and led by the CPC as the film implies. This is a typical type of positive portrayal, something that China's traditional 'Party journalism' is good at (Xin 2012).

With the help of the extended reach facilitated by social media, the video (including subtitles in English and Mandarin) seeks in a typical fashion to 'kill two birds with one stone', promoting simultaneously the party's internal and external publicity goals. From a political communication perspective, the video CPC is With You Along the Way is a typical example of a modern political advertisement, a campaigning tool widely used by parties in competitive political systems (Areddy 2014). The only novelty, perhaps, lies primarily in its handling of the small group of political, economic, technological, and cultural elites who have benefited most from China's modernisation and globalisation process. They appear very briefly in video clips or photos but are not specifically mentioned in the script/voiceover. In the background of the film there are glimpses of some 
of the star figures within Chinese society, such as Liu Xiang ${ }^{5}$, one of the most famous sportsmen in China; Yang Liwei ${ }^{6}$, the country's first astronaut; and the seven core members of the new generation of the top Chinese leadership (Politburo). But the actual voices heard in the video are deliberately only those of ordinary people - farmers, peasants, factory workers, pensioners, and schoolchildren - who talk about their personal dreams. Through this non-elitist narration, which is mostly inconsistent with China's contemporary social reality, the video tries to emphasise the 'power to the people' thesis, in order to pose a sharp contrast with the 2011 publicity film screened on Times Square. The latter was criticised by commentators for its 'elitist' approach to the promotion of the Chinese national image, framed mainly around the images of celebrities and elites (Zhao 2013). The elitist approach adopted in the 2011 film consequently resulted in a controversy among Chinese Internet users over who is entitled to represent China (Zhao 2013). The 2011 film, along with the controversy it caused, reveals the ideological tensions between the Chinese state's pursuit of soft power internationally and the decline of socialist ideology at home in a country where the social and economic gap between elite and non-elite groups has been enlarged to a concerning degree.

Through the film CPC is With You Along the Way, the party aims to reassert its goal to serve every ordinary citizen's 'Chinese dream' (Zhao 2015). This can also be seen as somehow proposing an alternative to Western neoliberal ideology, challenged by the recent financial crisis (2015). In this sense, the message embedded in the video is also ideological in nature, combining membership, action, goal and position devices identified by van Dijk. According to Zhao (2014; see also Zhao 2015), being ideological is not the cause of the problem. Ideology could actually be a possible solution to the issue of the gradual decline of public trust in today's China.

Here two notable devices are employed in the film. One is explicitly used to present the in-group as inclusive by showing representatives of various social and demographic groups, ranging from peasants to schoolchildren. This device helps to draw a clear-cut line between the new in-group and the old in-group of political, economic, technological and cultural elites portrayed in the 2011 publicity film. The second membership device is less explicit: although the film focuses solely on the 'Chinese dream', it implicitly reminds its audience that the former can be an alternative to the American dream, though, ideologically speaking, both dreams are similar. The combination of these two membership devices serve the ideological function of legitimating the CPC's leadership of the soft power project. However, the implicit use of the second membership device also implies that ideological clashes between socialist and capitalist ideologies are far from being reconciled, contrary to Fukuyama's prediction, although it is now less explicitly stated via mediated communication.

The CPC is With You Along the Way film tries to achieve similar 'soft power' objectives as the 2011 publicity film. The differences between these two films, however, need to be understood in relation to a broader social and cultural context. Since 2012 Chinese policymakers have had to think carefully about the 'power to whom' question, before rushing into endorsing lavish but not necessarily effective media and cultural initiatives overseas (Zhao 2014; see also Zhao 2015). The current slowing down of economic growth in China, a situation that is described as the 'new normal', has further

${ }^{5}$ Liu Xiang is an Olympic Gold Medallist (2004) and World Champion (2007) in the 110-meter hurdles.

${ }^{6}$ In 2003. Yang Liwei became the first person sent into space by China's manned spacecraft, Shenzhou 5. This mission made China the third country (after Russia and the USA) to independently send humans into space. 
forced policymakers into more careful thinking (Xin 2018). At the policy level, the power-for-whom question in the current economic circumstances requires policymakers to perform a new reality check in terms of China's soft power project. This reality check started with the primary group of state-owned national media and cultural organisations. These organisations are expected to be not only politically loyal to the party but also socially accountable to the people whom they are supposed to serve. Since the early 1980s, advertising has been gradually replacing state funds as the primary source of revenue for the vast majority of state-owned Chinese media, including China Central Television (CCTV) and Xinhua News Agency's newspapers. Serving rich and powerful advertisers has thus become an obvious business imperative for most party organs undergoing a market-oriented transition. Within the party there have been concerns over the prospects for state-owned news organisations (Zhao 1998; see also Zhao 2008; Xin 2006).

The dominant view is that if the major state-owned media and cultural players (who are the major recipients of state funds) do not become more socially accountable, they will eventually lose their domestic audiences - the people they are supposed to serve on behalf of the party and the country (Xin 2006). This is one of the main lessons that the party learned from the former Soviet Union's ultimate collapse in the early 1990s (Zhao 2008). The party's concerns have been growing in the recent decade. Having received special state funds for expanding their overseas operations since the early 2000s, some leading media players have now become the subject of recent corruption probes led by the party and the current government. In 2014, CCTV, the monopolist national TV broadcaster, had a number of star figures removed from their posts for alleged corruption. Among those were Rui Chenggang, China's most celebrated news presenter, and Guo Zhenxi, head of both advertising and the financial news channel (Clover 2014). Rumors about CCTV were spread both online and offline. In the same year, China Radio International (CRI) failed to pass inspection by China's anti-corruption watchdog. CRI was revealed to have breached rules in personnel and financial affairs, where power and money have become interchangeable commodities. The problem concerned the radio station's operations both at home and overseas.

The two cases above are probably just the tip of an iceberg, a symptom of a much more widespread problem with China's soft power mission-carriers, the majority of whom are struggling to meet both the party line and the bottom line under the 'new normal'. Thus, it remains to be seen whether China's soft power project will eventually be able to transform the leading central media organisations into effective generators of soft power, fulfilling their political, economic and social missions simultaneously.

Meanwhile, expanding economic disparities also affect the legitimacy of China's soft power project. With 40 million Chinese children still living in poverty and suffering from limited resources for education allocated at county and village level, it is hard to justify the billions of dollars of investment poured into the nearly 500 Confucius Institutes overseas. This has become a controversial issue in recent years ${ }^{7}$. There are also other challenges that the party has to handle: poverty, pollution, corruption, unemployment, and national security concerns, as well as the country's difficult relations with the USA, Japan, and other neighbouring countries. These thorny issues are generally referred to as the "untold challenges" in the CPC is With You Along the Way film. They are mostly identified as the party's new developmental goals to be achieved in the next

${ }^{7}$ http://paper.oeeee.com/nis/201501/20/319128.html, see also

http://news.xinhuanet.com/politics/2015-01/12/c 1113966711.htm (accessed on 4 December 2019). 
stage. Some of these issues are also integrated into the 'ordinary Chinese dreams' depicted in the film (as discussed earlier).

In addition to "development disparities", these "untold challenges" help to explain why the party under Xi's leadership feels it necessary to re-emphasise its goal to serve the entire Chinese population instead of a small group of the rich and powerful. This also seems to be in accord with Xi's "mass line" policy, aimed at strengthening the ties between the ordinary Chinese people and the party in the 'new normal' situation (Tiezzi 2013). However, their causes and socio-political impact, implications and ramifications are largely overlooked in the film. The omissions, intended or unintended, should be seen as one of the outcomes of the ongoing social and ideological struggles, placing at stake the CPC's credibility, control and, most of all, its exercise of power.

\section{Conclusion and Discussion}

It has been argued in this article that the CPC is With You Along the Way film is suggestive of an emerging process of re-ideologisation in China. More specifically, this can be described as ongoing efforts by Chinese authorities to revive the Chinese version of socialist ideology, a blend of Marxism, Leninism, and Mao Zedong Thought, as well as ancient Chinese philosophies. Key socialist values such as justice, equality, and community feature prominently in the film. What is at stake in this new drive towards re-ideologisation is the country's long-term search for ideological attraction within and outside China in spite of the struggles it faces. In this sense, CPC is With You Along the Way is a prominent mediated illustration of how the CPC is aiming to handle the 'soft-power-to-whom' issue, namely by reinforcing its socialist ideology with 'Chinese characteristics'. Here, again, the 'Chinese characteristics' mostly refer to those ideological features and the structural issues discussed in earlier sections that make China less attractive in terms of soft power and ideology. The 'Chinese characteristics' also include but are not limited to the omissions of certain important discourses in the discussion of China's soft power or the 'Chinese Dream'. They are equally vague when it comes to discussing the disparity issues and possible solutions, particularly those concerning the legitimacy of the CPC and the question of how 'socialist' China's system still is after the changes that have occurred since the early 1980s. The best alternative approach to handle these issues should be to openly address and discuss them, not necessarily in a publicity film, but through various inclusive and interactive channels among all social groups in society, held either offline or online.

The critical contextual and textual analysis of the film further illustrates that the 'soft power as ideology' thesis is not only theoretically useful for critically unpacking Nye's conception of soft power, which was originally only applied to the USA, but is also methodologically relevant to other cases such as China. Of course, a study based on the analysis of one film, no matter how prominent, must be careful to avoid making generalising claims. Therefore, it is hoped that this study is the starting point for a new line of academic enquiry within the wider soft power debate, a debate that has so far tended to ignore the '(soft) power-to-whom' question as well as the ideological implications in different social and political contexts. When it comes to China, the discussion has also tended to lose its contextual meanings, under the simplified umbrella label 'Chinese characteristics'. In this sense, this article advocates bringing the study of China's soft power within the central track of critical globalisation and ideology studies. Further studies will be needed to put China's soft power efforts under critical examination, in addition to a contextual and historical reality check. The latter is often unsatisfactorily dealt with in the existing literature on China's soft power. 


\section{References}

Appelbaum, Richard and William Robinson, eds. 2005. Critical Globalization Studies. London: Routledge.

Areddy, James T. 2014. You're in Good Hands with the Communists. Accessed 4 December 2019. http://on.wsj.com/19JIEv7

Barr, Michael. 2011. Who's Afraid of China? The Challenge of Chinese Soft Power. London: Zed Books.

BBC. 2013. What Does Xi Jinping's China Dream Mean? Accessed 4 December 2019. https://www.bbc.co.uk/news/world-asia-china-22726375

Callahan, William A. 2012. China: The Pessoptimist Nation. Oxford: Oxford University Press.

Chan, Joseph Man. 1993. Commercialization without Independence: Trends and Tensions of Media Development in China. In China Review 1993, edited by Joseph Yu-Shek Cheng and Maurice Brosseau, 25.1-25.21. Hong Kong: Chinese University Press.

Chase-Dunn, Christopher and Barry Gills. 2005. Waves of Globalization and Resistance in the Capitalist World-System: Social Movements and Critical Global Studies. In Critical Globalization Studies, edited by Richard Appelbaum and William Robinson, 45-54. London: Routledge.

Clover, Charles. 2014. China Central Television Purge Occurs Amid Corruption Probe. Accessed 4 December 2019. http://www.ft.com/intl/cms/s/0/fd18645a-0d7e-11e4-815f00144feabdc0.htm|\#axzz3WWlgDGhe

D'Mello, Bernard. 2009. What is Maoism? Economic and Political Weekly 44 (47): 39-48.

Eagleton, Terry. 2007. Ideology: An Introduction [2nd edition]. London: Verso.

Ferguson, Niall. 2003. Think again: Power. Foreign Policy (March/April): 18-24.

Fukuyama, Francis. 1992. The End of History \& the Last Man. London: Free Press.

Harvey, David. 2005. From Globalization to the New Imperialism. In Critical Globalization Studies, edited by Richard Appelbaum and William Robinson, 91-100. London: Routledge.

Kennedy, Paul. 2010. The Rise and Fall of the Great Powers. New York: Vintage.

Kissinger, Henry. 2012. On China. London: Penguin.

Lenin, Vladimir I. 1902/1987. What is to be Done? In Essential Works of Lenin: "What Is to Be Done?" and Other Writings, edited by Henry M. Christman, 53-176. New York: Dover Publications.

Li, Mingjiang. 2008. Soft Power in Chinese Discourse: Popularity and Prospect. Chinese Journal of International Politics 2 (2): 287-308.

MacKenzie, Lain. 1994. Introduction: The Arena of Ideology. In Political Ideologies: An Introduction, edited by Robert Eccleshall, Michael Kenny, and Vincent Geoghegan, 1-27 [2nd edition]. London: Routledge.

MacFarquhar, Roderick and Michael Schoenhals. 2008. Mao's Last Revolution. Cambridge, MA: Harvard University Press.

McGiffert, Carola, ed. 2009. Chinese Soft Power and its Implications for the United States: Competition and Cooperation in the Developing World: A Report of the CSIS Smart Power Initiative. Accessed 4 December 2019. https://csis-prod.s3.amazonaws.com/s3fs-public/legacy files/files/media/csis/pubs/090403 mcgiffert chinesesoftpower web.pdf

McLellan, David. 1995. Ideology [2nd edition]. Buckingham: Open University Press.

Nye, Joseph S. 2015. Is the American Century Over? Cambridge: Polity.

Nye, Joseph S. 2013. What China and Russia Don't Get about Soft Power. Foreign Policy. 29 April. Accessed 4 December 2019. https://foreignpolicy.com/2013/04/29/what-chinaand-russia-dont-get-about-soft-power/

Nye, Joseph S. 2011. The Future of Power. New York: Public Affairs.

Nye, Joseph S. 2008. The Powers to Lead. Oxford: Oxford University Press.

Nye, Joseph S. 2004. Soft Power: The Means to Success in World Politics. New York: Public Affairs.

Nye, Joseph S. 1990a. Soft Power. Foreign Policy 80: 153-171. 
Nye, Joseph S. 1990b. Bound to Lead: The Changing Nature of American Power. New York: Basic Books.

Rachman, Gideon. 2015. Book Review of “'Is the American Century Over?', by Joseph Nye. Financial Times, March 31. Accessed 4 December 2019. http://www.ftchinese.com/story/001061314/en?archive

Reisigl, Martin and Ruth Wodak. 2016. The Discourse-Historical Approach (DHA). In Methods of Critical Discourse Analysis, edited by Ruth Wodak and Michael Meyer, 23-61 [3rd edition]. London: Sage.

Robinson, William I. 2005. What is a Critical Globalization Studies? Intellectual Labor and Global Society. In Critical Globalization Studies, edited by Richard Appelbaum and William Robinson, 11-18. London: Routledge.

Servaes, Jan. 2016. The Chinese Dream Shattered between Hard and Soft Power? Media, Culture \& Society 38 (3): 437-449.

Shi, Anbin. 2018. China's Role in Remapping International Communication. In China's Media Go Global, edited by Daya Thussu, Hugo De Burgh, and Anbin Shi, 34-51. London: Routledge.

Snow, Nancy. 2009. Valuing Exchange of Persons in Public Diplomacy. In Routledge Handbook of Public Diplomacy, edited by Nancy Snow and Philip Taylor, 233-247. London: Routledge.

Suzuki, Shogo. 2010. The Myth and Reality of China's 'soft power'. In Soft Power and US Foreign Policy: Theoretical, Historical and Contemporary Perspectives, edited by Inderjeet Parmar and Michael Cox, 211-226. London: Routledge.

Taylor, Philip. 2010. Public Diplomacy and the Information War on Terror. In Soft Power and US Foreign Policy: Theoretical, Historical and Contemporary Perspectives, edited by Inderjeet Parmar and Michael Cox, 152-164. London: Routledge.

Taylor, Philip. 2009. Public Diplomacy and Strategic Communications. In Routledge Handbook of Public Diplomacy, edited by Nancy Snow and Philip Taylor, 12-16. London: Routledge.

Thussu, Daya. 2013. Communicating India's Soft Power: Buddha to Bollywood. New York: Palgrave Macmillan.

Tiezzi, Shannon. 2013. The Mass Line Campaign in the 21st Century. The Diplomat, December 27. Accessed 4 December 2019. https://thediplomat.com/2013/12/the-mass-line-campaign-in-the-21st-century/

van Dijk, Teun A. 1998. Ideology: A Multidisciplinary Approach. London: Sage.

Wang, Hongying and Yeh-Chung Lu. 2008. The Conception of Soft Power and Its Policy Implications: A Comparative Study of China and Taiwan. Journal of Contemporary China 17 (56): 425-447.

Wang, Huning. 1993. Culture as a Component of National Strength: Soft Power (in Chinese). Fudan Journal (Social Sciences Edition) 3: 91-96.

Xin, Xin. 2018. Financialization of News in China in the Age of the Internet: The Case of Xinhuanet. Media, Culture \& Society 40 (7): 1039-1054.

Xin, Xin. 2012. How the Market is Changing China's News: The Case of Xinhua News Agency. Lanham, MD: Lexington Books.

Xin, Xin. 2006. A Developing Market in News: Xinhua News Agency and Chinese newspapers. Media, Culture \& Society 28 (1): 45-66.

Zahran, Geraldo and Leonardo Ramos. 2010. From Hegemony to Soft Power: Implications of a Conceptual Change. In Soft Power and US Foreign Policy: Theoretical, Historical and Contemporary Perspectives, edited by Inderjeet Parmar and Michael Cox, 12-31. London: Routledge.

Zhang, Wei. 2015. 中国共产党英文宣传片你看过吗？Accessed 16 December 2019. http://www.xinhuanet.com/politics/2015-02/09/c 127473198.htm 
Zhao, Yuezhi. 2015. 赵月枝: 对外传播应大胆讲好“红色故事”. Accessed 10 February 2015. https://opinion.huanqiu.com/article/9CaKrnJHBKe

Zhao, Yuezhi. 2014. 什么是中国故事的力量之源: 全球传播格局与文化领导权之争 (On the Chinese Story's Source of Power -The Global Pattern of Information Spread and Cultural Leadership Competition). Frontiers (《人民论坛·学术前沿》) 24: 34-43.

Zhao, Yuezhi. 2013. China's Quest for “Soft Power": Imperatives, Impediments and Irreconcilable Tensions? The Public/Javnost: Journal of the European Institute for Communication and Culture 20 (4): 17-30.

Zhao, Yuezhi. 2012. The Struggle for Socialism in China: The Bo Xilai Saga and Beyond. Monthly Review 64 (5): 1-17.

Zhao, Yuezhi. 2008. Communication in China: Political Economy, Power, and Conflict. Lanham, MD: Rowman \& Littlefield.

Zhao, Yuezhi. 1998. Media, Market, and Democracy in China: Between the Party Line and the Bottom Line. Urbana: University of Illinois Press.

\section{About the Author}

Xin Xin

Dr. Xin Xin is Reader in International Communication at the University of Westminster, UK. 